\title{
Understanding internationalisation through the lens of social network analysis
}

DOI:

10.1007/978-1-137-56946-2_14

\section{Document Version}

Accepted author manuscript

Link to publication record in Manchester Research Explorer

\section{Citation for published version (APA):}

Kurt, Y., \& Yamin, M. (2016). Understanding internationalisation through the lens of social network analysis. In $\mathrm{H}$. Tüselmann, S. Buzdugan, Q. Cao, D. Freund, \& S. Golesorkhi (Eds.), Impact of International Business: Challenges and solutions for policy and practice (Vol. 23, pp. 241-264). (Academy of International Business (UKI) Series). Palgrave Macmillan Ltd. https://doi.org/10.1007/978-1-137-56946-2_14

\section{Published in:}

Impact of International Business

\section{Citing this paper}

Please note that where the full-text provided on Manchester Research Explorer is the Author Accepted Manuscript or Proof version this may differ from the final Published version. If citing, it is advised that you check and use the publisher's definitive version.

\section{General rights}

Copyright and moral rights for the publications made accessible in the Research Explorer are retained by the authors and/or other copyright owners and it is a condition of accessing publications that users recognise and abide by the legal requirements associated with these rights.

\section{Takedown policy}

If you believe that this document breaches copyright please refer to the University of Manchester's Takedown Procedures [http://man.ac.uk/04Y6Bo] or contact uml.scholarlycommunications@manchester.ac.uk providing relevant details, so we can investigate your claim.

\section{OPEN ACCESS}




\title{
Understanding Internationalisation through the Lens of Social Network Analysis
}

\author{
Yusuf Kurt • Mo Yamin
}

\section{This is an Author's Original Manuscript (AAM) of an article published by Palgrave in "AIB-UKI Book Series (23); Impact of International Business; Challenges and Solutions for Policy and Practice. Please cite the published article:}

Kurt, Yusuf and Mo Yamin (2016), "Understanding internationalisation through the lens of social network analysis," in Impact of international business - challenges and solutions for policy and practice, Heinz Tüselmann, Stephen Buzdugan, Qi Cao, David Freund, and Sougand Golesorkhi (Eds.) Vol. 23. Houndmills, Basingstoke, Hampshire, U.K.: Palgrave Macmillan, 241-264. (DOI: 10.1007/978-1-137-56946-2_14). http://dx.doi.org/10.1007/978-1-137-56946-2_14

\section{Authors}

\section{Yusuf Kurt}

Lecturer (Assistant Professor) in International Business and Management

The University of Manchester, Alliance Manchester Business School

Booth Street West, Manchester M15 6PB, UK.

(e-mail: yusuf.kurt@manchester.ac.uk,

www.manchester.ac.uk/research/yusuf.kurt)

\section{Mo Yamin}

Professor of International Business

The University of Manchester, Alliance Manchester Business School

Booth Street West, Manchester M15 6PB, UK.

(e-mail: mo.yamin@manchester.ac.uk, www.manchester.ac.uk/research/mo.yamin) 


\section{Introduction}

The notion of 'networks' has been applied by a growing number of researchers in different business and management sub-disciplines including organisational studies (Salancik, 1995; Uzzi, 1996; Zaheer and Bell, 2005; Kilduff and Brass, 2010; Tichy et al., 1979), knowledge management (Cross and Parker, 2004; Reagans and McEvily, 2003), innovation (Freeman, 1991; Ahuja, 2000; Dhanaraj and Parkhe, 2006) and international business and marketing (Coviello and Munro, 1997, 1995; Ellis, 2000, 2011; Johanson and Vahlne, 2009; Zhou et al., 2007; Sharma and Blomstermo, 2003; Tikkanen, 1998; Mattsson, 1997; Johanson and Mattsson, 1985). However, while the notion of networks has been a potent idea in the social sciences (Borgatti et al., 2009), most application of the network concept has been criticised for being 'merely descriptive' (ibid.) and not going beyond loose metaphorical narratives.

The advent of Social Network Analysis (SNA) in visualising relationships through mapping social interconnections (sociograms) has enabled a significant shift from loose metaphorical narratives on network relationships to more precise outputs on web of invisible ties among social actors (Knox et al., 2006). SNA can reveal interdependence between social actors and its consequences through employing SNA-specific measurements such as centrality, density and size. The significance of SNA resides in its reference to the importance of social structures, which has been ignored under methodologically individualistic approaches in social science research that has overlooked the interdependence of all social actors through networks (Borgatti and $\mathrm{Li}, 2009$ ) and thus the potential of social network analysis still remains widely untapped.

In international business and particularly in the literature on firm internationalisation there has been a move away from focusing on firms as 'atomistic agents' and towards considering the importance of network linkage and dependence, most sharply demonstrated by the significant revision in the Uppsala model of firm internationalisation (Johanson and Vahlne, 1977, 2009). More broadly, the role of networking and network dependency has been extensively focused in the international business (IB) and internationalisation literatures (Coviello, 2006). However, the key shortcoming has been that the systematic utilisation of social network theories and along with that the application of SNA as an analytical tool to investigate network dimensions (e.g. network density, centrality, reciprocity, frequency, network size and so forth) has been rare. To sum up, even though the SNA hold a great potential, the level of its application as an analytical and methodological tool in internationalisation research is far behind from its potential. 
This study aims to highlight the potential value of SNA for the IB research, particularly in the context of firm internationalisation. The arguments are developed with reference to the revised Uppsala model in which internationalisation is regarded as overcoming liability of outsidership and building insidership in the relevant networks. The intended contribution of the present study is to demonstrate the potential of SNA, as an analytical tool, in providing better understanding of network insidership and outsidership in internationalisation research. We specifically argue that:

(a) investigating how the liability of outsidership can effectively be overcome requires a bifocal perspective, namely one that focuses on the firm that seeks an insider position in a relevant network ('outside-in') and also one that considers the perspective of an insider considering to 'open doors' for the outsider ('inside-out')

(b) both the 'outside-in' and the 'inside-out' perspectives are strongly shaped by the structural and positioning features of social networks. This then leads to considering the SNA as a descriptive tool regarding structural and positional attributes of networks that inform the analysis of the relationship between network attributes and the overcoming of the liability of outsidership.

The remainder of the chapter is structured as follows. Section 2 provides an overview on the application of network approaches in various studies in the IB literature. Section 3 provides a synopsis of SNA, emphasising the key constructs and measures that constitute the core tools of the analysis and also what internationalisation implications may be generated from the application of these tools. Section 4 is devoted to understanding internationalisation process from LOO perspective and bringing SNA into the research context. In the last section, concluding remarks will be given with implications for practice and directions for future SNA-applied internationalisation research.

\section{Network perspectives in IB research}

The debate on whether firms' internal resources and capabilities or external resources constitute firms' competitive advantages, which is seen as a prerequisite of success in international operations, has a long history in the literature (Barney, 1991; Gulati, 1999; Gulati et al., 2000). Whereas the Resource-Based View (RBV) has exclusively focused on internal resources and capabilities of firms, the network literature has highlighted 'the importance of external resources available to the firm through its networks' (Zaheer and Bell, 2005, p. 809). Scholars' interest in network approach has gradually increased over time, and has extended and enriched the RBV approach (e.g. Luo, 2003; Lavie, 2006; Chetty and Agndal, 2007; Kiss and Danis, 2008; Zhou, Wu and Luo, 2007). 
The network concept has also been influential via the 'market-as-networks' (MAN) approach (Johanson and Mattsson, 1992; Mattsson, 1997; McLoughlin and Horan, 2002; Johanson and Vahlne, 2011). As highlighted by Johanson and Mattson (1992), markets are understood as systems of networks of relationships among social and economic actors who are highly interdependent (Johanson and Mattsson, 1988, 1994; McLoughlin and Horan, 2002). Johanson and Vahlne (2011, p. 485) proposed that markets are networks of business relationships and importantly regarded internationalisation as a process of building insidership position in the relevant network of the targeted market, overcoming the liability of outsidership.

While the network concept has influenced internationalisation research via the network extension of the RBV and the MAN approaches, the influence of another important network approach, namely social network theory and the SNA, has, by comparison, been very rare. This is illustrated in Table 13.1 below which provides overviews of a representative number of recent studies on internationalisation in which the network concept has been a key element.

Table 13.1 Selected studies applying network approach

\begin{tabular}{|c|c|c|c|}
\hline Study/Journal & $\begin{array}{l}\text { Motivation for applying network } \\
\text { approach }\end{array}$ & Analytical lens & $\begin{array}{l}\text { Application } \\
\text { of SNA }\end{array}$ \\
\hline $\begin{array}{l}\text { Johanson and } \\
\text { Vahlne ( } 2009, \\
\text { Journal of } \\
\text { International } \\
\text { Business Studies) }\end{array}$ & $\begin{array}{l}\text { '[M]arkets are networks of relationships in } \\
\text { which firms are linked to each other in } \\
\text { various, complex and, to a considerable } \\
\text { extent, invisible patterns. . our original } \\
\text { model needs to be developed further in light } \\
\text { of such clear evidence of the importance of } \\
\text { networks in the internationalization of firms.' } \\
\text { (p. 1411) }\end{array}$ & $\begin{array}{l}\text { Markets-as-Networks View } \\
\text { 'Our core argument is based on } \\
\text { business network research ... markets } \\
\text { are networks of relationships in which } \\
\text { firms are linked to each other in } \\
\text { various, complex and, to a } \\
\text { considerable extent, invisible } \\
\text { patterns.' (p. 1411) }\end{array}$ & Not Applied \\
\hline $\begin{array}{l}\text { Coviello and } \\
\text { Munro (1995, } \\
\text { European Journal } \\
\text { of Marketing) }\end{array}$ & $\begin{array}{l}\text { 'In particular, the research focuses on their } \\
\text { use of network relationships to pursue foreign } \\
\text { market opportunities and conduct } \\
\text { international marketing activities. This } \\
\text { research article endeavours to offer new } \\
\text { insights into the international market } \\
\text { development activities . . . the objective of } \\
\text { this article is to examine the impact of } \\
\text { network relationships on: (1) international } \\
\text { market development, and (2) marketing- } \\
\text { related activities within international } \\
\text { markets.' (pp. 49-51) }\end{array}$ & $\begin{array}{l}\text { Markets-as-Networks View } \\
\text { 'In network theory, markets are } \\
\text { depicted as a system of relationships } \\
\text { among a number of players including } \\
\text { customers, suppliers, competitors and } \\
\text { private and public support agencies.' } \\
\text { (p. } 50)\end{array}$ & Not Applied \\
\hline
\end{tabular}




$\begin{array}{lll}\begin{array}{l}\text { Coviello (2006, '[T]he purpose of this study is to assess the } \\ \text { Journal of }\end{array} & \begin{array}{l}\text { Structural/Positional Approach } \\ \text { network dynamics of INVs. Our focus is on }\end{array} & \text { '... the general question guiding this } \\ \text { International } & \begin{array}{l}\text { INV networks rather than the INV per se, and } \\ \text { the network is positioned as the "dependent }\end{array} & \begin{array}{l}\text { research: what are the network } \\ \text { dynamics of INVs in terms of the }\end{array} \\ \text { Business Studies) } & \begin{array}{l}\text { variable."' (p. 714) } \\ \text { structural and interactional patterns at }\end{array} & \text { various stages of evolution?' (p. 717) }\end{array}$

Extension of Resource-Based

Loane and Bell '[T]he focus ... is on networking dimensions
(2006,

International

Marketing

Review)

of rapid internationalisation; namely, on how decision-makers acquire, develop, maintain and exploit networks, on the nature of such networks in terms of "strong" or "weak" ties and on their specific impact upon internationalisation activities.' (p. 471)
View

Not Applied

'Following a synthesis of the extant international networking literature and the integration of resource- and knowledge based views (RBV and

$\mathrm{KBV}$ ) of internationalisation, we describe the research approach adopted in the present enquiry.' (p. 468)

\begin{tabular}{|c|c|c|c|}
\hline $\begin{array}{l}\text { Elg, Ghauri and } \\
\text { Tarnovskaya } \\
(2008, \\
\text { International } \\
\text { Marketing } \\
\text { Review) }\end{array}$ & $\begin{array}{l}\text { 'We argue that the position achieved by a } \\
\text { firm as it establishes itself on an emerging } \\
\text { market will depend on whether it is able to } \\
\text { perform efficient matching and networking } \\
\text { activities on that market or not.... This study } \\
\text { sets out to augment our understanding of the } \\
\text { role of a retailer's stakeholder relationships } \\
\text { on different levels during market entry by } \\
\text { applying a network approach.' (pp. 676-677) }\end{array}$ & $\begin{array}{l}\text { Markets-as- Networks View } \\
\text { 'It is therefore important to look into } \\
\text { the role of relationships with different } \\
\text { types of socio-political actors in the } \\
\text { process of entering an emerging } \\
\text { market.' (p. 675) }\end{array}$ & Not Applied \\
\hline $\begin{array}{l}\text { Kontinen and } \\
\text { Ojala ( } 2011, \\
\text { International } \\
\text { Business Review) }\end{array}$ & $\begin{array}{l}\text { 'The aim of this study was to understand how } \\
\text { the network ties of family SMEs function in } \\
\text { recognizing opportunities to enter foreign } \\
\text { markets.' (p. 441) }\end{array}$ & $\begin{array}{l}\text { Markets-as-Networks View } \\
\text { 'Internationalization is related to the } \\
\text { development of network ties with } \\
\text { other firms belonging to a network in } \\
\text { a foreign market. These ties between } \\
\text { firms in different markets act as } \\
\text { bridges facilitating foreign market } \\
\text { entry.' (p. 441) }\end{array}$ & Not Applied \\
\hline $\begin{array}{l}\text { Zhou, Wu and } \\
\text { Luo ( } 2007, \\
\text { Journal of } \\
\text { International } \\
\text { Business Studies) }\end{array}$ & $\begin{array}{l}\text { 'We draw on the social network theories and } \\
\text { explain the performance implications of } \\
\text { internationalization in SMEs. In line with the } \\
\text { theorization of internationalization of SMEs } \\
\text { as a process of social dynamics through } \\
\text { networking strategies ... we postulate a } \\
\text { mediating mechanism of social networks } \\
\text { underlying the relationship between } \\
\text { internationalization orientations and } \\
\text { performance outcomes.' (p. 675) }\end{array}$ & $\begin{array}{l}\text { Extension of Resource-based } \\
\text { View } \\
\text { 'We explain that internationally } \\
\text { oriented SMEs deploy home-based } \\
\text { social networks as an efficient means } \\
\text { of obtaining information } \\
\text { resources.... The central foundation } \\
\text { of social network theories is the } \\
\text { transmission of knowledge or useful } \\
\text { information through interpersonal ties }\end{array}$ & Not Applied \\
\hline
\end{tabular}




\begin{tabular}{|c|c|c|c|}
\hline & & $\begin{array}{l}\text { and social contacts with individuals.' } \\
\text { (p. 676) }\end{array}$ & \\
\hline $\begin{array}{l}\text { Sharma and } \\
\text { Blomstermo } \\
\text { (2003; } \\
\text { International } \\
\text { Business Review) }\end{array}$ & $\begin{array}{l}\text { 'The purpose of this paper is to contribute to } \\
\text { the development of theory by explaining the } \\
\text { internationalization process of Born Globals. } \\
\text { We propose that models emphasising } \\
\text { knowledge and (network) ties are suitable for } \\
\text { this purpose. This is appropriate because the } \\
\text { ties that firms have may help them to go } \\
\text { international by supplying information about } \\
\text { clients and markets.' (p. 740) }\end{array}$ & $\begin{array}{l}\text { Extension of Resource-based } \\
\text { View } \\
\text { 'Network research emphasizes the } \\
\text { importance of inter-firm ties in } \\
\text { accumulating and utilizing } \\
\text { knowledge. ... Firms' ties provide } \\
\text { channels for sharing knowledge as } \\
\text { well as the motivation to do so.' (p. } \\
744)\end{array}$ & Not Applied \\
\hline $\begin{array}{l}\text { Coviello (2005, } \\
\text { Qualitative } \\
\text { Market Research: } \\
\text { An International } \\
\text { Journal) }\end{array}$ & $\begin{array}{l}\text { '. . a method enabling empirical assessment } \\
\text { of both the structure of the network and the } \\
\text { nature of the interactions/relationships } \\
\text { between network actors is required. What } \\
\text { then, is the appropriate method by which to } \\
\text { conduct such an analysis? To address this } \\
\text { question, we turn to a discussion of how to } \\
\text { assess network structure and interactions over } \\
\text { time by applying a bifocal analytic lens to the } \\
\text { research method.' (p. } 42 \text { ) }\end{array}$ & $\begin{array}{l}\text { Structural/Positional Approach } \\
\text { 'Network research is multi- } \\
\text { dimensional in that it can involve } \\
\text { analysis of network size and structure, } \\
\text { the interactional processes by which } \\
\text { network structures are created ... } \\
\text { empirical assessment of both the } \\
\text { structure of the network and the } \\
\text { nature of the interactions/relationships } \\
\text { between network actors is required.' } \\
\text { (pp. 39-42) }\end{array}$ & Partially Applied \\
\hline $\begin{array}{l}\text { Hilmersson and } \\
\text { Jansson (2012, } \\
\text { Internal Business } \\
\text { Review) }\end{array}$ & $\begin{array}{l}\text { '[W]e address two core aspects associated } \\
\text { with the business network entry process ... } \\
\text { we assess how the SME initiates and develops } \\
\text { relationships when plugging into the new } \\
\text { business network. . . . Our theory is centred } \\
\text { on four core constructs developed from } \\
\text { literature: network structures and positions, } \\
\text { entry nodes and processes. It is a synthesis of } \\
\text { established theories and constructs relevant } \\
\text { for examining how SMEs establish } \\
\text { insidership positions in institutionally } \\
\text { different business networks.' (pp. 683-685) }\end{array}$ & $\begin{array}{l}\text { Structural/Positional Approach } \\
\text { 'We address the entire network } \\
\text { evolvement process in the local } \\
\text { foreign market by studying how the } \\
\text { entrant firm's network position } \\
\text { develops over time as it moves from } \\
\text { outsidership to insidership.' (p. 683) }\end{array}$ & Not Applied \\
\hline $\begin{array}{l}\text { Yli-Renko, Autio } \\
\text { and Tontti (2002, } \\
\text { International } \\
\text { Business Review) }\end{array}$ & $\begin{array}{l}\text { 'In this study, we attempt to capture both the } \\
\text { "network structural" and "relational" aspects } \\
\text { of social capital and to look at the exchange } \\
\text { and assimilation of both tacit and explicit } \\
\text { information. ... The model aims at } \\
\text { explaining the role of intra- and inter- } \\
\text { organizational relationships in building the } \\
\text { firm's distinctive knowledge base and in } \\
\text { achieving international growth.' (p. 282) }\end{array}$ & $\begin{array}{l}\text { Extension of Resource-based } \\
\text { View } \\
\text { 'We will lay out our arguments on } \\
\text { how firms can leverage social capital } \\
\text { in their external relationships to } \\
\text { facilitate knowledge acquisition and } \\
\text { experiential learning ... social } \\
\text { networks provided entrepreneurs with }\end{array}$ & Not Applied \\
\hline
\end{tabular}




\begin{tabular}{|c|c|c|c|}
\hline & & $\begin{array}{l}\text { access to external information and } \\
\text { advice, as well as other resources.' } \\
\text { (pp. 284-285) }\end{array}$ & \\
\hline $\begin{array}{l}\text { Chetty and } \\
\text { Agndal (2007, } \\
\text { Journal of } \\
\text { International } \\
\text { Marketing) }\end{array}$ & $\begin{array}{l}\text { 'Using the network approach, the authors } \\
\text { develop three categories of social capital and } \\
\text { discuss their role in influencing mode change. } \\
\ldots \text { We contribute to the change in } \\
\text { internationalization mode literature by using } \\
\text { the network approach as a framework... we } \\
\text { focus on the resources that a firm acquires } \\
\text { through its network, which is referred to as } \\
\text { social capital, and how this influences the } \\
\text { change in internationalization mode.' (pp. 1- } \\
\text { 6) }\end{array}$ & $\begin{array}{l}\text { Extension of Resource-based } \\
\text { View } \\
\text { 'One of the major constraints for } \\
\text { small and medium-sized enterprises } \\
\text { (SMEs) as they go through the } \\
\text { internationalization process is that } \\
\text { they lack resources ... a way to } \\
\text { overcome this limitation is for firms } \\
\text { to acquire these resources through } \\
\text { their business networks.' (p. 2) }\end{array}$ & Not Applied \\
\hline $\begin{array}{l}\text { Ojala }(2009, \\
\text { International } \\
\text { Business Review) }\end{array}$ & $\begin{array}{l}\text { '[T]his study is aimed to analyze firms' } \\
\text { activities in developing network relationships, } \\
\text { their focal network relationships, and the } \\
\text { impact of these relationships to the market } \\
\text { and entry mode choice of knowledge- } \\
\text { intensive SMEs when they enter a psychically } \\
\text { distant market for their products . . } \\
\text { contributes to the network theory in the } \\
\text { context of internationalization of knowledge- } \\
\text { intensive SMEs by analyzing market entries } \\
\text { in settings where firms are entering an } \\
\text { attractive but psychically distant market for } \\
\text { their products.' (p. 51) }\end{array}$ & $\begin{array}{l}\text { Markets-as- Networks View } \\
\text { 'Firms' network relationships have } \\
\text { been seen as the major initiators in the } \\
\text { internationalization process where } \\
\text { firms are following their networks to } \\
\text { foreign markets ... network } \\
\text { relationships can act as a bridge to } \\
\text { foreign markets.' (p. } 50 \text { ) }\end{array}$ & Not Applied \\
\hline
\end{tabular}

Even though the majority of internationalisation studies have not explicitly considered the relevance of social network theories and the SNA, their relevance has nevertheless been acknowledged by key authors (Coviello, 2006; Johansson and Vahlne, 2009; Vahlne and Johanson, 2013) who have indicated that networks are dynamic and thus revealing structural and interactional dynamics of networks is quite important to understanding their effect on internationalisation (Coviello, 2006). Vahlne and Johansson (2013), while upholding the MAN perspective, acknowledged that inter-firm relationships display different structural patterns of interconnections. Building insidership positions in the relevant network provides several advantages for firms, such as improving dynamic capabilities, learning, internationalising and accessing resources (ibid.). However, structures of the network in which firms build their insidership position affect the value of insidership for the firm. Thus, while the MAN perspective can potentially inform the internationalisation process (e.g. Ojala, 2009; Elg et al., 2008), the full realisation of this potential may require revealing the structures of networks where firms build their 
insidership position. In a similar vein Johanson and Vahlne (2009, p. 1413) have observed that 'the research that has been done to date generally has studied the ways in which networks influence internationalisation, without discussing how those networks have been created, and without considering the network structure in the country or countries firms entered'.

We conclude that a key motivation for applying social network theory and hence the SNA is the observation that network resources are differentially available to firms. As noted by Ter Wal and Boschma (2009, p. 741), 'it is a rule rather than an exception that networks will be unevenly distributed among firms'. The type of opportunities available to firms is dependent on the characteristics of their relationships and network structure (Andersson et al., 2005). In other words, finding and exploiting opportunities is contingent on firms' network structure and relationships. There is no objective opportunity which is evenly distributed to all firms in a network. Different network structures and actor positions generate different advantages. Therefore, through employing a robust social network methodology built on social network theory, the system of resource dissemination can be revealed more systematically by mapping the relationships.

\section{What is social network analysis?}

In their seminal book, Wasserman and Faust (1994, p. 20) defined social network as 'a finite set or sets of actors and the relation or relations defined on them'. Different level and type of social units (e.g. individuals, firms, organisations, and non-human agents) are regarded as actors in social network analysis (Borgatti and Li, 2009; Contractor et al., 2006). Network-based research aims to find out how actors are connected to one another and thus influence one another's behaviour (connectionist view), or how their interactions are affected by the structure of overall network (structuralist view) (Hennig et al., 2013). SNA holds an advantage of providing visual descriptions of relationships through using mathematical and graphical techniques (Hanneman and Riddle, 2005). Employing SNA, which allows sophisticated analysis and comparisons of network characteristics, will enable the researcher to 'trace the deeper aspects of the network in its social context; address the organisation system or network as a whole; capture important dynamic dimensions of the network' (Coviello, 2005, p. 43). As network perspectives enable better representation and explanation for complex dependencies which would not be captured in population samples, more and more phenomena are being conceptualised under network paradigms (Hennig et al., 2013). In methodological application of SNA, there are two main constructs: network structure and positioning. 
Actors in a network are not equally positioned; while some actors are centrally positioned and occupy critical positions, others are located in less strategic positions. An actor's position can affect the level of potential resources that can be exploited by the actor and its control power within the network. For instance, centrally positioned actors that have higher number of direct ties have advantage in terms of accessing more network assets and less chance of missing vital resources such as information and knowledge (Bell, 2005). Likewise different network structural attributes also create distinctive outcomes such as different level of information, opportunity, and strategic resources. SNA offers some measurements through which an actor's centrality or their number of direct ties can be revealed. The measurements for detecting actor positioning include degree centrality, betweenness centrality and structural holes, whereas measurements for network structures include density, cohesiveness and core-periphery (Giuliani and Pietrobelli, 2011). Even though a wide variety of measurements are available in SNA, whole-network measures are grouped into two as cohesion and shape measures (Borgatti et al., 2013). In order to clarify measurement understandings, some widely used measurements are explained in Table 13.2.

Table 13.2 Structural and positioning measurements of SNA

\begin{tabular}{|c|c|c|c|}
\hline SNA measurements & Illustration & Description & $\begin{array}{l}\text { Implications for } \\
\text { internationalisation }\end{array}$ \\
\hline $\begin{array}{l}\text { Degree Centrality } \\
\text { (Actor Positioning } \\
\text { Construct) } \\
\text { Degree Centrality } \\
\text { (continued) }\end{array}$ & & $\begin{array}{l}\text { It indicates an actor's } \\
\text { number of direct ties in the } \\
\text { network. Node A has higher } \\
\text { degree centrality with high } \\
\text { number of direct ties to other } \\
\text { nodes. An actor's degree } \\
\text { centrality can be calculated } \\
\text { without getting network data } \\
\text { of the whole network in } \\
\text { which the actor is embedded. }\end{array}$ & $\begin{array}{l}\text { Connection a nodal partner (A) } \\
\text { with high degree centrality in the } \\
\text { relevant network provides better } \\
\text { access to market information, } \\
\text { knowledge and resources for the } \\
\text { focal company. Higher centrality } \\
\text { leads accessing more network } \\
\text { resources and information. The } \\
\text { nodal partner has more flexibility } \\
\text { in having willingness and ability } \\
\text { to 'open the doors' for the focal } \\
\text { firm to become an insider, as it is } \\
\text { not restricted by dense network } \\
\text { structure. }\end{array}$ \\
\hline $\begin{array}{l}\text { Eigenvector Centrality } \\
\text { (Actor Positioning }\end{array}$ & & $\begin{array}{l}\text { Nodes that are tied to well- } \\
\text { connected nodes have higher } \\
\text { eigenvector centrality. Even } \\
\text { though node A and B have } \\
\text { same degree of centrality, } \\
\text { node A has higher score as it } \\
\text { is connected to a central }\end{array}$ & $\begin{array}{l}\text { Connecting to a nodal partner (B) } \\
\text { that has high degree centrality in } \\
\text { the targeted network can increase } \\
\text { the focal firms' access to more } \\
\text { market information and } \\
\text { knowledge requiring for } \\
\text { internationalisation. The nodal }\end{array}$ \\
\hline
\end{tabular}




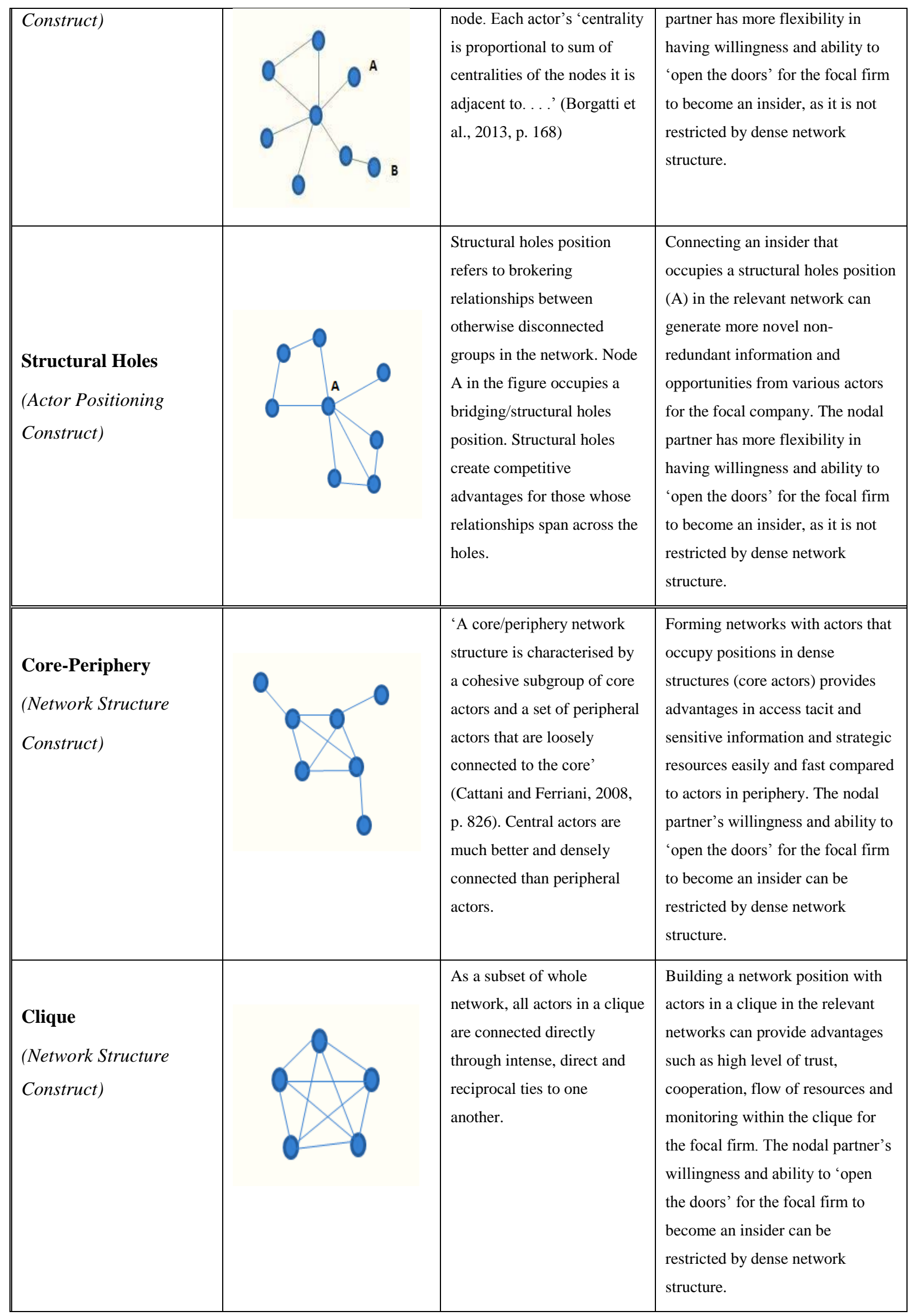

Source: Adapted from Giuliani and Pietrobelli (2011). 


\section{Internationalisation from liability of outsidership perspective}

In the original Uppsala Model, internationalisation was defined as a gradual and incremental process though which firms increase their foreign market commitment starting from the markets that have lower psychic distance (Johanson and Vahlne, 1977). In the revisited models overcoming liability of foreignness to relevant foreign markets was replaced by overcoming liability of outsidership to the relevant networks through importing business network approach into their research (Johanson and Vahlne, 2003, 2009). The importance of networks in internationalisation was strongly emphasised by indicating that 'internationalisation process is pursued in a network' by Johanson and Vahlne (2009, p. 1424). Liability of outsidership was proposed as the fundamental barrier for internationalisation and opportunity recognition in foreign markets. Outsidership is regarded as the source of uncertainty for internationalising firms and it is stated that 'outsidership, in relation to the relevant network ... is the root of uncertainty' (ibid., p. 1411). As markets comprise a complex and invisible web of relationships, being an insider in a relevant network decreases uncertainty and risk perception about foreign markets, and hence facilitate internationalisation process. A firm which is well positioned in the relevant network is defined as an 'insider'. On the other hand, a firm which does not have a well-established position in the relevant network which may be an outcome of liability of foreignness is known as 'outsider' (Johanson and Vahlne, 2009). Firms suffer from liability of outsidership when they have no network position in the targeted foreign market networks. Although 'insidership' was offered as crucial to the internationalisation process, how this status is gained is not considered in sufficient detail. The authors implied that the process through which 'outsidership ' is overcome may be due to happenstance: when a potential partner in a relevant network starts doing business with the focal firm through an ad hoc order, or firms can intentionally seek a network to build insidership position.

\section{The process of overcoming the liability of outsidership}

In order to better understand the process through which outsidership is overcome we need to address two main issues; (a) whether the process is passive or an active one where firms deliberately take steps to compensate for their outsidership through strategically building insider positions; (b) how is the process of building insidership affected by key structural attributes of the 'targeted' networks and positional attributes of connected actors.

The question of whether firms actively and deliberately seek networks to overcome liability of outsidership or follow an autonomous evolutionary process needs to be clarified (Johanson and Vahlne, 2009; 
Schweizer, 2013). The formation of relationships with actors from targeted networks can be either an active or passive process. In their buyer-seller activeness-passiveness comparison, Johanson and Mattsson (1988) addressed that active networking initiatives are taken proactively by sellers, whereas in passive networking sellers reactively respond to the initiations taken by buyers. Building on Johanson and Vahlne's (2009) active networking refers to a systematic search of an outsider for relevant networks and actors, yet passive networking happens as a result of ad-hoc events between insider and outsider, such as unsolicited orders (Johanson and Vahlne, 2006; Kontinen and Ojala, 2011). There are two related -perspectives: social network and resourcebased view which discuss whether overcoming the liability of outsidership and network creation is a passive or active process. Social network view argues that firms are relatively passive and the liability of outsidership is overcome through developing previously existing networks as an evolutionary process over time. This perspective argues that relationships evolve organically though existing relationships and circumstances (Chetty and Patterson, 2002). On the other hand, the other perspective, based on RBV view, argues that firms seek and form new relationships depending on their lack of resources, and thus they compensate their competitive disadvantages (Ahuja, 2000; Schweizer, 2013). Therefore, firms consciously build relationships and become insiders in a strategically chosen network in order to acquire complementary resources necessary for internationalisation. Even though both perspectives bring some important points onto the stage, resource-based view, which emphasises a more conscious and active firm behaviour in network seeking, has come to prominence in many studies (e.g. Hite and Hesterly, 2001; Larson and Star, 1993; Crick and Spence, 2005; Gilmore et al., 2006; Loane and Bell, 2006; Ojala, 2009). The relevance of active network-seeking in knowledge acquisition and foreign market expansion has been emphasised in several studies (Loane and Bell, 2006; Gabrielsson et al., 2008; Ojala, 2009). Similarly, from SNA point of view, we build our arguments that firms taking deliberate internationalisation decisions actively seek their target networks. So, internationalisation and overcoming the liability of outsidership can be seen as an outcome of deliberate actions. Otherwise, if a firm only responds to the opportunities emerging coincidentally, it means the firm does not really have a deliberate intention to internationalise; thus it may end up in a market serendipitously. Hence, revealing or knowing network structures and attributes provide no benefit to them. Besides, these two perspectives are not mutually exclusive. Building an insidership position is an ongoing process, hence firms can both follow their existing relationships for further network formation and actively seek networks based on the resources they lack or need. For instance, firms can initially learn about the targeted networks through existing relationships, which are not 
necessarily with the actors from the target market. This process eventually enables firms to become more familiar with the targeted network, and then build strategic insidership positions.

\section{Network dependency of overcoming liability of outsidership}

Overcoming the liability of outsidership (LOO) is a bilateral engagement and requires motivation and commitment of both insider(s) and the outsider. Therefore, it is necessary to take structural and positional attributes of networks in which the outsider seeks to build an insidership position. So, a broader lens that covers both 'outside-in' and 'inside-out' perspectives is required. However, this process accommodates both benefits and risks. As indicated by Johanson and Vahlne, (2001, p. 19), 'to enter a network from outside requires that other actors have to be motivated to engage in interaction, something which is resource demanding, and which may require several firms to make adaptations in their ways of performing business'.

Building an insidership in the targeted networks requires not only outsider's motivation and initiatives but also insider's motivation to open the doors for the outsider which is resource demanding. Moreover, insiders' behaviours are network dependent, as they are dependent on one another's resource and sanction. Thus, network structure and actor positioning are important determinants of insider's behaviours for accepting the outsider into the network. In the extant literature, network-based models have been mainly argued through two structural perspectives: structural holes and network closure. Basically these two arguments are grounded in the social capital phenomena. Social capital is defined as 'the sum of the actual and potential resources embedded within, available through, and derived from the network of relationships possessed by an individual or social unit' (Nahapiet and Ghoshal, 1998, p. 243). Even though there have been various definitions of social capital by many scholars (e.g. Coleman, 1988; Burt, 1992; Lin, 1999), ‘. . they agree on a social-capital metaphor in which social structure is a kind of capital that can create for certain individuals or groups a competitive advantage in pursuing their ends' (Burt, 2008, p. 32).

Although social capital arguments admit that actors doing better are those who are better connected, disagreements are based in different perspectives on the meaning of 'better connected' (ibid.). Network closure approach advocates that social capital is generated in dense network structures. On the other hand, structural holes argument asserts that brokering otherwise connected networks creates social capital. From internationalisation and LOO perspectives, rather than building a one-way argument on whether network closure or structural holes are more beneficial, it is necessary to conceptualise in what conditions and for which outcomes denser or sparser networks can generate better return. A more beneficial return of insidership position 
can be achieved when the type of network structure matches with the type of necessary market knowledge. Previous studies (Hansen, 1999; Uzzi, 1996; Reagans and McEvily, 2003; Granovetter, 1985) indicated that strong ties and network closure promote the flow of complex tacit knowledge, whereas structural holes and weak ties enable tapping into simple information in a timely manner. Tacitness can be defined as 'the degree to which knowledge is difficult to codify (e.g. in writing) and articulate' (Reagans and McEvily, 2003, p. 245). So strong networks and cohesive network structures can work more efficiently when the outsider is seeking tacit knowledge. On the contrary, weak ties or open network can promote the flow of market-related information and codifiable knowledge, which is the case when the psychic distance is low. Hence, network structure does not only affect the motivations of insider and outsider to interact but also their ability to exchange resources. So, it is initially necessary to build a comprehensive understanding of network structure under Coleman's (1988) and Burt's (1992) social capital arguments, before bringing SNA to the stage as a network structure-revealing tool.

\section{Network closure - cohesion}

One of the mainstream network-based social capital perspectives is network closure which emphasises the positive impact of dense network structures on developing trust and cooperative exchanges (Gargiulo and Benassi, 2000). Based on the question of how certain groups can generate more or less social capital, Coleman (1994) have extensively focused on network closure as a source of social capital. Basically, Coleman's (1988, 1994) view of social capital asserts that networks with closure, in which all actors are connected, generate more social capital. According to Coleman (1994) network closure creates network properties such as norms, trust and sanctions which curb opportunism, foster mobilisation of network resources among and generation of social capital for group members. Cooperative behaviours and trust among actors can be enhanced within closely connected network structures. As highlighted by Gargiulo and Benassi (2000) network closure surrounding an actor determines the level social capital available to him/her. Network closure facilitates information and knowledge flows among network members, especially tacit type of knowledge (Reagans and McEvily, 2003). On the other hand, building relationships in densely connected regions of the network requires relatively higher level of resource investment in order to maintain strong relations, compared to building weak ties. Willingness and motivation of actors to deal with these costs can be stimulated with certain values provided by dense networks such as effective diffusion of tacit knowledge, supporting relations, building legitimacy in the network and so on. 
Network closure can provide strong support and sponsorship for becoming legitimate players in the market. Adler and Kwon (2002, p. 25) indicated that 'closure provides social capital's cohesiveness benefits within an organisation or community; structural holes in the focal actor's external linkages provide cost-effective resources for competitive action'. Network closure increases trust and decreases the competitive and motivational impediments, and thus facilitates flow of knowledge and information (Reagans and McEvily, 2003). Insiders can be more cooperative in sharing knowledge and information when strong third party ties surround a relationship, and cooperative norms and trust are created (Reagans and McEvily, 2003). Social cohesion can increase the motivation and willingness of insiders to devote resources and time to assist network members (ibid.). However, since network members are highly interdependent it could be hard to create space for a newcomer which can serve as a drawback of network cohesion in the targeted network.

\section{Network range - structural holes}

Alternatively, open networks are proposed as the potential sources of generating social capital (Burt, 1992). It was indicated that bridging positions between densely connected regions generates more social capital as an outcome of brokerage function (Walker et al., 1997). The actors whose relationships span over the holes in social structure, otherwise unconnected regions, have an advantage of accessing and controlling the flow of nonredundant resources and information. Burt's perspective argues that open networks provide more flexibility for actors whereas closed networks reduce actors' independence (Walker et al., 1997). Not only flexibility, occupying a bridging position across structural holes also provides advantages such as accessing higher volume of novel and non-redundant information from separate groups and controlling flow of information in a timely manner. By contrast with these assets, open networks cannot provide the same benefit of curbing opportunistic actions as closed networks (Ahuja, 2000). Sparse networks maximise information benefits through exploiting structural holes and exchanging information between various actors from different social, organisation and institutional boundaries (Reagans and McEvily, 2003; Hilmersson and Jansson, 2012). Closed networks are more efficient in diffusion of tacit and market-specific information, while open networks provide the advantage of accessing explicit knowledge and novel information. However, closed networks require a relatively higher level of investment into the networks. Hence, a trade-off exists for actors while building insidership position in closed or open networks. 


\section{Network-dependent insider and outsider motivations to overcome LOO}

Structural attributes of targeted networks affect both the network value for outsider and also insider's motivation to facilitate network entry of outsider. 'Network value for outsider' refers to the outsider's evaluation about the value of forming relationships to achieve an insidership position. If an outsider believes that the value of building insidership is high, the motivation for investing more resources will also be higher. The outsider's value assessment might be based on cost-benefit analysis. For instance, building an insidership in a dense targeted network requires high level of time and resource investment, which involves extra cost. However, if the targeted network is in a highly psychically distant market, in which the outsider needs tacit market information, support and legitimacy, the benefits of the insidership can balance the cost. On the other hand, 'insider's motivation to facilitate network entry' represents how eager the insider is to create a space for the outsider, which is affected by the value evaluation of the insider, and constraints arise from the structure of the insider's network. For instance, insiders who are strongly embedded in cohesive networks cannot have enough flexibility and autonomy to create new space for an outsider without getting sanctions from the others. Even though network cohesion facilitates cooperation, safety and creation of social capital, they may also impede network actors from entering into or promoting new cooperative relationships with actors from the outside of its network (Gargiulo and Benassi, 2000). The rigidity of cohesive networks can be seen as the 'dark side' which eventually affects the flexibility of the insider actors. Since these two network attributes are not mutually exclusive, insiders in cohesive dense networks might want to build relationships in order to balance their cohesiveness benefits with structural holes' opportunities through bridging to an outsider. As indicated by Reagans, Zuckerman and McEvily (2004), most productive teams are those which can combine internal cohesive structure with external networks with structural holes. So it can be said that optimal network needs to combine elements of both cohesion and range depending of the type of necessary knowledge for internationalisation (Reagans and McEvily, 2003).

\section{Understanding LOO from SNA lenses}

Social network analysis enables examining how different attributes of network structures affect the resource exchange (Haythornthwaite, 1996). Since building insidership position is a way of accessing necessary market-related information and resources, SNA can help to reveal how different network structures affect the value of the insidership. The value of different network structures - cohesion or range - can vary in different contexts, depending on what actors look for and seek to achieve (Stam et al., 2014). Hence, internationalising firms should decide which type of network structure and position would be better to build an insidership 
depending on their requirements. Even though both closure and sparse networks can generate benefits, from the liability of outsidership perspective, the value of these networks depends on various other circumstances, such as other sources of social capital, type of information and degree of liability of foreignness. From liability of outsidership perspective, the value of network closure or structural holes can vary depending on psychic distance between markets in which insider's and outsider's networks are embedded. Overcoming the liability of outsidership may not enable the overcoming liability of foreignness to the same extent. The value of insidership position changes in relation to the psychic distance and thus the liability of foreignness. Building insidership position in sparse networks can be effective when psychic distance is low. However, if the psychic distance is high then it is more efficient to build insidership position in closure network structures in order to access tacit and market-specific knowledge. For instance, when the uncertainty is high and there is less commonality between the environments of the insider and outsider - including institutional commonalities - it could be beneficial to build an insidership position into densely connected networks. Value of insidership positions can be better understood through revealing network structures and actor positioning which can be revealed with analytical techniques provided by SNA (Haythornthwaite, 1996). The SNA-related measurements given on Table 13.3 will be evaluated in the light of two phenomena: psychic distance and type of necessary knowledge.

Here, a few SNA-related network measurements help us to understand how different network structure can affect insidership position of an actor from social capital and structural holes perspectives. Insidership position is created through connecting the target network, however the benefits may vary based on different network structures, actor positioning and to whom the actor is connected. Not only actor's own positioning but also the position of the connected actor (insider) in the targeted network is crucial. The level of benefits insidership position generates depends highly on the level of resources that the connected actors can access. Therefore, the level of insidership also should be assessed through taking the connected actor's position into account. Along with its measurements regarding actor positioning and network structures such as centrality, structural holes and core-periphery, SNA can work as a significant tool to investigate the value of insidership for both outsider and insider. 
Table 13.3 Value of insidership positions with social capital/structural holes perspectives

\begin{tabular}{|c|c|c|c|}
\hline $\begin{array}{l}\text { SNA } \\
\text { measurements }\end{array}$ & Illustration & $\begin{array}{l}\text { Value of insidership } \\
\text { position }\end{array}$ & $\begin{array}{l}\text { Social capital/structural } \\
\text { holes perspectives }\end{array}$ \\
\hline $\begin{array}{l}\text { Betweenness } \\
\text { Centrality }\end{array}$ & & $\begin{array}{l}\text { If a firm builds its insidership } \\
\text { position through connecting } \\
\text { an actor with high } \\
\text { betweenness centrality in the } \\
\text { targeted network, this may } \\
\text { increase the level of } \\
\text { opportunities and resources } \\
\text { accessed through insidership } \\
\text { position as the connected } \\
\text { actor's position generates } \\
\text { abundant resources, } \\
\text { information and control } \\
\text { power. Hence, the more } \\
\text { information and resources can } \\
\text { be obtained, the liability of } \\
\text { foreignness can be decreased. }\end{array}$ & $\begin{array}{l}\text { From Burt's (1992) structural } \\
\text { holes point of view, building an } \\
\text { insidership position through } \\
\text { connecting an actor with high } \\
\text { betweenness centrality shows } \\
\text { the presence of structural holes } \\
\text { in an open network provides } \\
\text { cost-effective resources and } \\
\text { information, as actor A has } \\
\text { control power over the flow of } \\
\text { information and resources } \\
\text { within the sparse network. This } \\
\text { insidership position can work } \\
\text { efficiently when the liability of } \\
\text { foreignness of outsider is not } \\
\text { very high. It could be easier to } \\
\text { build insidership compared to } \\
\text { dense networks. }\end{array}$ \\
\hline $\begin{array}{l}\text { Structural } \\
\text { Holes }\end{array}$ & & $\begin{array}{l}\text { If the firm builds its } \\
\text { insidership position through } \\
\text { connecting with an actor } \\
\text { occupying bridging position } \\
\text { in the targeted network, this } \\
\text { may enhance the level of } \\
\text { novel information and } \\
\text { resources the firm can access } \\
\text { through this click. Besides, if } \\
\text { connecting a foreign network } \\
\text { makes the firm a bridge } \\
\text { between its own network and } \\
\text { the targeted network this } \\
\text { insidership position may also } \\
\text { generate more resources } \\
\text { compared to non-bridging } \\
\text { positions. }\end{array}$ & $\begin{array}{l}\text { Connecting an actor that } \\
\text { occupies a bridging position can } \\
\text { enable the outsider to build } \\
\text { insidership position through } \\
\text { accessing cost-effective resource } \\
\text { and information, as in Burt's } \\
\text { (1992) structural holes } \\
\text { argument. Structural holes } \\
\text { position does not provide the } \\
\text { benefits of dense networks, so } \\
\text { this may not work effectively } \\
\text { with a network from markets } \\
\text { with high psychic distance, as } \\
\text { decreasing the liability of } \\
\text { foreignness requires more tacit } \\
\text { information about markets. }\end{array}$ \\
\hline & & $\begin{array}{l}\text { Since core actors mostly } \\
\text { occupy advantageous } \\
\text { positions which enable them }\end{array}$ & $\begin{array}{l}\text { From Coleman's (1988) } \\
\text { perspective; building insidership } \\
\text { through connecting to the }\end{array}$ \\
\hline
\end{tabular}




\begin{tabular}{|l|l|l|l|}
\hline Core & $\begin{array}{l}\text { to access more information } \\
\text { and resources, building an } \\
\text { insidership position through } \\
\text { connecting core actors in } \\
\text { targeted network (network tie } \\
\text { A) can increase the level of } \\
\text { resources and information } \\
\text { obtained. Connecting } \\
\text { peripheral actors (Network } \\
\text { connected can provide } \\
\text { cie B) may generate low level } \\
\text { capital. Under more effective } \\
\text { norms and trust, the more tacit } \\
\text { social capital is generated in } \\
\text { densely connected structural } \\
\text { areas of the network. It could be } \\
\text { harder to form networks with } \\
\text { foreign market which does not } \\
\text { decrease the liability of } \\
\text { compared to the peripheral } \\
\text { foreignness. }\end{array}$ & $\begin{array}{l}\text { actors which are not restricted } \\
\text { with dense connections. }\end{array}$ \\
\hline
\end{tabular}

Firms' network positions determine whether they are outsider or insider of the targeted foreign network structures. Not only firm position but also structure of networks (e.g. open versus closed networks) in foreign market networks is also given as an important determinant of insidership position. Regarding network structures, plugging into an open network can benefit through providing information from various weak ties and reducing the degree of insidership of the information network (Hilmersson and Jansson, 2012). On the other hand, connecting to a closed network with strong ties, which mostly forms the core of the targeted local business network, enables achieving insidership. Hence, both firms' network positioning and structures of foreign market network determine the status of insidership and the degree of insidership. Hilmersson and Jansson (2012, p. 686) asserted the degree of insidership as the critical aspect of networks. They indicated that the degree of insidership is related to the degree of coupling of the local network, the control of network and competitive position.

Therefore, it can be concluded that degree of insidership is one of the key network determinants which influence firm internationalisation. The questions at this point should be how we can accurately measure a firm's degree of insidership for understanding network outcomes on internationalisation. It requires a systematic analytical research tool which provides specific measurement constructs through which the degree of insidership can be determined. Moreover, the evolutionary process of business networks while a firm is shifting from an outsider position to insider position was given in three stages: exposure network, formation network and sustenance network in the study of Hilmersson and Jansson (2012). 


\section{Conclusion and applications}

This research brings SNA into the internationalisation research context as an innovative and comprehensive methodological tool in parallel with the call 'networks need to be investigated with appropriate methodologies' (Zucchella et al., 2007, p. 277) in the IB literature. In today’s world economy, 'quite literally, networks are reshaping the global business architecture' (Parkhe et al., 2006, p. 560). This status quo of the global marketplace increases the necessity for applying a broader lens which takes network relationships into account while investigating drivers and outcomes of firm behaviours. Similarly, internationalisation behaviours and performance of firms can be better understood in their network contexts. This was highlighted by (Gulati et al., 2000, p. 203) as 'the conduct and performance of firms can be more fully understood by examining the network of relationships in which they are embedded'. Therefore, the IB field requires innovative methodologies that could add the missing invisible component to the broad picture in a systematic way and make significant advances in our knowledge, as the traditional research tools fail to provide a robust analysis on network interdependencies.

On the other hand, firm internationalisation has been one of the main research themes of the IB literature and has been widely studied in different research contexts. Network view taken in recent studies in the IB literature could not go beyond a descriptive approach. However, as a systematic research tool borrowed from sociology, SNA provides various structural and positional dimensions through which the effect of networks on firm internationalisation can be better understood. Similarly, this study also shows how different network attributes facilitate or impede the overcoming the LOO through benefiting from SNA. The impact of network attributes in overcoming LOO is focused from both outside-in and inside-out perspectives. Revealing structural and positional attributes of networks through employing SNA-based measurements demonstrates how structures of networks and actors' position affect overcoming liability of outsidership in internationalisation process. The impact of structural and positional attributes of networks is discussed in relevance to psychic distance phenomenon, which affects the type of knowledge an internationalisation firm requires.

As discussed, overcoming liability of outsidership and being an insider in a targeted network is seen as a prerequisite for internationalisation. However, forming and sustaining relationships are resource-demanding which creates a burden especially for small firms which experience lack of resources. In that manner, firms should actively and deliberately seek certain network structures within their targeted foreign markets, depending on the type of knowledge and support they require. For instance, building insidership in an open network in a market with close psychic distance, which requires relatively lower investment, can work effectively for 
internationalising firm. Yet this requires a systematic analysis to reveal the network dynamics and structures. Therefore, SNA also provides practical implications for firms and managers, as they can benefit from this systematic analytical tool for revealing network structures and hence developing their strategies in building insidership positions in foreign markets. Future research should benefit from SNA in internationalisation research, especially through applying a longitudinal approach which can demonstrate evolution of structural and positional attributes of network at different stages of internationalisation.

\section{References}

Adler, P.S. and Kwon, S.W. (2002). 'Social capital: Prospects for a new concept', Academy of Management Review, 27(1), 17-40.

Ahuja, G. (2000). 'Collaboration networks, structural holes, and innovation: A longitudinal study', Administrative Science Quarterly, 45(3), 425-455.

Andersson, U., Holm, D.B. and Johanson, M. (2005). 'Opportunities, relational embeddedness and network structure'. In A. Hadjikhani, P. Ghauri, and J. Johanson (eds), Managing Opportunity Development in Business Networks. Basingstoke, UK: Palgrave Macmillan.

Barney, J. (1991). 'Firm resources and sustained competitive advantage', Journal of Management, 17(1), 99-120.

Bell, G.G. (2005). 'Clusters, networks, and firm innovativeness', Strategic Management Journal, 26(3), 287-295.

Borgatti, S.P., Everett, M.G. and Johnson, J.C. (2013). Analyzing Social Networks. New York: Sage Publications.

Borgatti, S.P. and Li, X. (2009). 'On social network analysis in a supply chain context', Journal of Supply Chain Management, 45(2), 5-22.

Borgatti, S.P., Mehra, A., Brass, D.J. and Labianca, G. (2009). 'Network analysis in the social sciences', Science, 323(5916), 892-895.

Burt, R.S. (1992). 'The social structure of competition', In N. Nohria, and R. Eccles (eds), Networks and Organisations: Structure, Form, and Action. New York: Harvard Business School Press.

— (2008). 'Structural holes versus network closure as social capital'. In N. Lin, K. Cook, and R.S. Burt (eds), Social Capital: Theory and Research. New Brunswick, NJ: Transaction Publishers.

Chetty, S. and Agndal, H. (2007). 'Social capital and its influence on changes in internationalisation mode among small and medium-sized enterprises', Journal of International Marketing, 15(1), $1-29$.

Chetty, S. and Patterson, A. (2002). 'Developing internationalisation capability through industry groups: The experience of a telecommunications joint action group', Journal of Strategic Marketing, 10(1), 69-89.

Coleman, J.S. (1988). 'Social capital in the creation of human capital', American Journal of Sociology, 94(1), 95-120.

— (1994). Foundations of Social Theory. Cambridge, MA: Harvard University Press.

Contractor, N.S., Wasserman, S. and Faust, K. (2006). 'Testing multitheoretical, multilevel hypotheses about organisational networks: An analytic framework and empirical example', Academy of Management Review, 31(3), 681-703. 
Coviello, N.E. (2005). 'Integrating qualitative and quantitative techniques in network analysis', Qualitative Market Research: An International Journal, 8(1), 39-60.

(2006). 'The network dynamics of international new ventures', Journal of International Business Studies, 37(5), 713-731.

Coviello, N.E. and Munro, H.J. (1995). 'Growing the entrepreneurial firm: Networking for international market development', European Journal of Marketing, 29(7), 49-61.

Coviello, N.E. and Munro, H. (1997). 'Network relationships and the internationalisation process of small software firms', International Business Review, 6(4), 361-386.

Crick, D. and Spence, M. (2005). 'The internationalisation of "high performing" UK high-tech SMEs: A study of planned and unplanned strategies', International Business Review, 14(2), 167-185.

Cross, R.L. and Parker, A. (2004). The Hidden Power of Social Networks: Understanding How Work Really Gets Done in Organisations. New York: Harvard Business Press.

Dhanaraj, C. and Parkhe, A. (2006). 'Orchestrating innovation networks', Academy of Management Review, 31(3), 659-669.

Elg, U., Ghauri, P.N. and Tarnovskaya, V. (2008). 'The role of networks and matching in market entry to emerging retail markets', International Marketing Review, 25(6), 674-699.

Ellis, P. (2000). 'Social ties and foreign market entry', Journal of International Business Studies, 31(3), 443-469.

(2011). 'Social ties and international entrepreneurship: Opportunities and constraints affecting firm internationalisation', Journal of International Business Studies, 42(1), 99-127.

Freeman, C. (1991). 'Networks of innovators: A synthesis of research issues', Research Policy, 20(5), 499-514.

Gabrielsson, M., Kirpalani, V., Dimitratos, P., Solberg, C.A. and Zucchella, A. (2008). 'Born globals: Propositions to help advance the theory', International Business Review, 17(4), 385-401.

Gargiulo, M. and Benassi, M. (2000). 'Trapped in your own net? Network cohesion, structural holes, and the adaptation of social capital', Organisation Science, 11(2), 183-196.

Gilmore, A., Carson, D. and Rocks, S. (2006). 'Networking in SMEs: Evaluating its contribution to marketing activity', International Business Review, 15(3), 278-293.

Giuliani, E. and Pietrobelli, C. (2011). 'Social network analysis methodologies for the evaluation of cluster development programs', Inter-American Development Bank, 1-46.

Granovetter, M. (1985). 'Economic action and social structure: The problem of embeddedness', American Journal of Sociology, 91(3), 481-510.

Gulati, R. (1999). 'Network location and learning: The influence of network resources and firm capabilities on alliance formation', Strategic Management Journal, 20(5), 397-420.

Gulati, R., Nohria, N. and Zaheer, A. (2000). 'Guest editors' introduction to the special issue: Strategic networks', Strategic Management Journal, 21(3), 199-201.

Hanneman, R.A. and Riddle, M. (2005). Introduction to Social Network Methods. Riverside, CA: University of California, Riverside (online textbook).

Hansen, M.T. (1999). 'The search-transfer problem: The role of weak ties in sharing knowledge across organisation subunits', Administrative Science Quarterly, 44(1), 82-111.

Haythornthwaite, C. (1996). 'Social network analysis: An approach and technique for the study of information exchange', Library and Information Science Research, 18(4), 323-342.

Hennig, M., Brandes, U., Pfeffer, J. and Mergel, I. (2013). Studying Social Networks: A Guide to Empirical Research. Chicago: Campus Verlag/University of Chicago Press. 
Hilmersson, M. and Jansson, H. (2012). 'International network extension processes to institutionally different markets: Entry nodes and processes of exporting SMEs', International Business Review, 21(4), 682-693.

Hite, J.M. and Hesterly, W.S. (2001). 'The evolution of firm networks: From emergence to early growth of the firm', Strategic Management Journal, 22(3), 275-286.

Johanson, J. and Mattsson, L.G. (1985). 'Marketing investments and market investments in industrial networks', International Journal of Research in Marketing, 2(3), 185-195.

(1988). 'Internationalisation in industrial systems: A network approach'. In N. Hood, and J. Vahlne (eds), Strategies in Global Competition. New York: Routledge.

- (1992). Network Positions and Strategic Action: An Analytical Framework. London: Routledge.

(1994). The Markets-as-Networks Tradition in Sweden. London: Springer.

Johanson, J. and Vahlne, J.E. (1977). 'The internationalisation process of the firm: A model of knowledge development and increasing foreign market commitments', Journal of International Business Studies, 8(1), 23-32.

(2001). 'The Mechanism of Internationalisation', International Marketing Review, 7(4), 11-24.

(2003). 'Business relationship learning and commitment in the internationalisation process', Journal of International Entrepreneurship, 1(1), 83-101.

(2006). 'Commitment and opportunity development in the internationalization process: A note on the Uppsala internationalization process model', Management International Review, 46(2), 165-178.

_ (2009). 'The Uppsala internationalisation process model revisited: From liability of foreignness to liability of outsidership', Journal of International Business Studies, 40(9), 1411-1431.

(2011). 'Markets as networks: Implications for strategy-making', Journal of the Academy of Marketing Science, 39(4), 484-491.

Kilduff, M. and Brass, D.J. (2010). 'Job design: A social network perspective', Journal of Organisational Behavior, 31(2-3), 309-318.

Kiss, A.N. and Danis, W.M. (2008). 'Country institutional context, social networks, and new venture internationalisation speed', European Management Journal, 26(6), 388-399.

Knox, H., Savage, M. and Harvey, P. (2006). 'Social networks and the study of relations: Networks as method, metaphor and form', Economy and Society, 35(1), 113-140.

Kontinen, T. and Ojala, A. (2011). 'Network ties in the international opportunity recognition of family SMEs', International Business Review, 20(4), 440-453.

Larson, A. and Starr, J. A. (1993). 'A network model of organization formation', Entrepreneurship theory and practice, 17, 5-5.

Lavie, D. (2006). 'The Competitive Advantage of Interconnected Firms: An Extension of the Resource-Based View', Academy of Management Review, 31(3), 638-658.

Lin, N. (1999). 'Building a network theory of social capital', Connections, 22(1), 28-51.

Loane, S. and Bell, J. (2006). 'Rapid internationalisation among entrepreneurial firms in Australia, Canada, Ireland and New Zealand: An extension to the network approach', International Marketing rejview, 23(5), 467-485.

Luo, Y. (2003). 'Industrial dynamics and managerial networking in an emerging market: The case of China', Strategic Management Journal, 24(13), 1315-1327.

Mattsson, L.G. (1997). “Relationship marketing” and the "markets-as-networks approach": A comparative analysis of two evolving streams of research', Journal of Marketing Management, 13(5), 447-461. 
McLoughlin, D. and Horan, C. (2002). 'Markets-as-networks: Notes on a unique understanding', Journal of Business Research, 55(7), 535-543.

Nahapiet, J. and Ghoshal, S. (1998). 'Social capital, intellectual capital, and the organisational advantage', Academy of Management Review, 23(2), 242-266.

Ojala, A. (2009). 'Internationalisation of knowledge-intensive SMEs: The role of network relationships in the entry to a psychically distant market', International Business Review, $18(1), 50-59$.

Parkhe, A., Wasserman, S. and Ralston, D.A. (2006). 'New frontiers in network theory development', Academy of Management Review, 31(3), 560-568.

Reagans, R. and McEvily, B. (2003). 'Network structure and knowledge transfer: The effects of cohesion and range', Administrative Science Quarterly, 48(2), 240-267.

Reagans, R., Zuckerman, E. and McEvily, B. (2004). 'How to make the team: Social networks vs. demography as criteria for designing effective teams', Administrative Science Quarterly, 49(1), 101-133.

Salancik, G.R. (1995). 'Wanted: A good network theory of organisation', Administrative Science Quarterly, 40(2), 345-349.

Schweizer, R. (2013). 'SMEs and networks: Overcoming the liability of outsidership', Journal of International Entrepreneurship, 11(1), 80-103.

Sharma, D.D. and Blomstermo, A. (2003). 'The internationalisation process of Born Globals: A network view', International Business Review, 12(6), 739-753.

Stam, W., Arzlanian, S. \& Elfring, T. (2014). 'Social capital of entrepreneurs and small firm performance: A meta-analysis of contextual and methodological moderators', Journal of business venturing, 29(1), 152-173.

Ter Wal, A. and Boschma, R.A. (2009). 'Applying social network analysis in economic geography: Framing some key analytic issues', The Annals of Regional Science, 43(3), 739-756.

Tichy, N.M., Tushman, M.L. and Fombrun, C. (1979). 'Social network analysis for organisations', Academy of Management Review, 4(4), 507-519.

Tikkanen, H. (1998). 'The network approach in analyzing international marketing and purchasing operations: A case study of a European SME's focal net 1992-95', Journal of Business and Industrial Marketing, 13(2), 109-131.

Uzzi, B. (1996). 'The sources and consequences of embeddedness for the economic performance of organisations: The network effect', American Sociological Review, 61(4), 674-698.

Vahlne, J.E. and Johanson, J. (2013). 'The Uppsala model on evolution of the multinational business enterprise: From internalisation to coordination of networks', International Marketing Review, 30(3), 189-210.

Walker, G., Kogut, B. and Shan, W. (1997). 'Social capital, structural holes and the formation of an industry network', Organisation Science, 8(2), 109-125.

Wasserman, S. and Faust, K. (1994). Social Network Analysis: Methods and Applications (vol. 8). Cambridge: Cambridge University Press.

Yli-Renko, H., Autio, E. and Tontti, V. (2002). 'Social capital, knowledge, and the international growth of technology-based new firms', International Business Review, 11(3), 279-304.

Zaheer, A. and Bell, G.G. (2005). 'Benefiting from network position: Firm capabilities, structural holes, and performance', Strategic Management Journal, 26(9), 809-825.

Zhou, L., Wu, W. and Luo, X. (2007). 'Internationalisation and the performance of born-global SMEs: The mediating role of social networks', Journal of International Business Studies, 38(4), 673690.

Zucchella, A., Palamara, G. and Denicolai, S. (2007). 'The drivers of the early internationalisation of the firm', Journal of World Business, 42(3), 268-280. 